\title{
Developments in the supply of direct international air services from airports in Scotland
}

\author{
Romano Pagliari ${ }^{1}$ \\ Centre for Air Transport in Remoter Regions, Cranfield University
}

\begin{abstract}
Scotland's location, limited population size and absence of major base carriers have served to constrain the development of direct international air services. Air service liberalisation has altered the degree to which different segments of the international passenger market are served at each airport. Overall, air service provision has been enhanced by the activities of Ryanair at Prestwick, long-haul airlines operating to Glasgow and the use of regional jets by franchise carriers at Aberdeen and Edinburgh. These initiatives, to a large extent, were as a result of promotional efforts undertaken by the airport operators. The Scottish Executive-administered Interim Route Development Fund has been less effective in this regard.
\end{abstract}

Key words air services, Scotland, Scottish airports, international connectivity.

\section{$1 \quad$ Introduction}

Airlines have often struggled to sustain commercially viable direct air services to international destinations from airports in Scotland. Examples have included the loss of several transatlantic flights from Glasgow in the mid 1990s and the more recent collapse of Duo's network of international services from Edinburgh in May 2004. Apart from Ryanair, major UK-based low cost airlines have chosen not to establish

\footnotetext{
${ }^{1}$ Fax 01234 752207, r.pagliari@cranfield.ac.uk
} 
networks of international services at Scottish airports, preferring instead to expand at airports located in other regions of the UK. These developments have helped contribute to a widespread perception amongst policy-makers that Scotland is poorly served with direct international connections and that this may have adverse implications for the performance and competitiveness of the Scottish economy, particularly in its ability to attract inward investment (Mackinlay, 1999). For multinational corporations, air services can have a direct impact on the competitiveness of internationally focussed businesses through the facilitation of better customer and supplier relationships (Hughes, 2004).

It is within this context that the aim of this paper is to evaluate developments in the provision of direct international air services from airports in Scotland. The following two key questions will be addressed:

- How has the level and pattern of direct international air services changed historically at Scottish airports?

- What factors have shaped the provision of direct air services and to what extent have they constrained or enhanced connectivity?

\section{Current level of air service provision}

Scotland has a population of approximately five million, with the majority residing in the cities of Edinburgh and Glasgow (See Figure 1). Scheduled international air services are offered at four airports, Aberdeen, Edinburgh, Glasgow and Prestwick ${ }^{2}$. The busiest is Glasgow, which handled 8.1 million passengers in 2003, followed by Edinburgh, which handled 7.4 million. The third busiest is Aberdeen, which handled

\footnotetext{
2 Norwegian carrier Wideroe operated a twice-weekly service in Summer 2004 between Sumburgh (Shetland Islands) and Oslo.
} 
2.5 million, while 1.8 million passengers passed through Prestwick. Aberdeen, Edinburgh and Glasgow are owned and operated by BAA Scotland (subsidiary of BAA), while Prestwick airport is owned by New Zealand-based utilities company, Infratil.

Glasgow primarily functions as the principal gateway for both long-haul scheduled and international charter services in Scotland. It's closest competitor is Prestwick, which is located $56 \mathrm{~km}$ to the South of the city and is home to Ryanair's Scottish hub, where international "no-frills" services are offered to the secondary airports of several major European cities. At Edinburgh Airport, which serves Scotland's capital city, direct scheduled services are offered by various regional airlines to several European gateway airports, while the importance of the oil industry to Aberdeen is apparent in the range of services that are scheduled to airports in the North Sea region. Table 1 lists the top fifteen international routes in terms of 2003 passenger traffic volume. Amsterdam, Dublin, Frankfurt and Paris are the dominant passenger markets.

\section{Analysis of changes in the supply of direct international scheduled services}

\section{8-2003}

Figure 2 shows the number of international destinations served with direct non-stop services at the four airports between 1988 and $2004^{3}$. Prior to 1990, Glasgow and Prestwick functioned as Scotland's international gateway airports, the former focussing on short-haul services and the latter serving the transatlantic market. In 1990, the removal of traffic distribution rules, which granted Prestwick Airport exclusive gateway status on transatlantic routes from Scotland, expedited the transfer

\footnotetext{
${ }^{3}$ Direct services are defined as those connections that are non-stop and do not involve a stop to set down and pick up passengers nor a change of aircraft at an intermediate airport.
} 
of Air Canada and Northwest Airlines scheduled services to Glasgow. This was followed by the launch of new direct transatlantic flights from Glasgow offered by American Airlines (Chicago), British Airways (New York JFK) and United Airlines (Washington). All of these services were subsequently withdrawn or reduced to seasonal operations by the late 1990s.

Scheduled services were resumed at Prestwick in 1994 when it was selected as Ryanair's Scottish base ${ }^{4}$. The low cost carrier selected Prestwick after managing to secure a five-year exemption from paying aeronautical charges (Calder 1994). International services were further expanded after 1999 with the launch of direct flights to the secondary airports of several European cities ${ }^{5}$. Although Prestwick is disadvantaged relative to Glasgow in terms of distance from key population centres, this is to some extent offset by the availability of a direct rail connection. In promoting its services, Ryanair used Prestwick's rail network accessibility to its advantage by offering free rail travel from any station in Scotland on purchase of a Ryanair ticket. These incentives combined with the marketing and availability of attractive fares enabled Ryanair to expand at Prestwick at the expense of Glasgow, where there was a decline in the number of short-haul international direct services between 1994 and 2002. During this period, the airport lost direct services to Brussels (Sabena), Frankfurt (Lufthansa) and Paris CDG (Air France).

While Glasgow has struggled in developing and sustaining short-haul connections, it has established itself as the preferred Scottish gateway for long-haul services, all offered by non-UK based carriers (Air Canada, Air Transat, American, Continental,

\footnotetext{
${ }^{4}$ Initial destinations served were Dublin and London Stansted.

${ }^{5}$ Barcelona (Gerona), Brussels (Charleroi), Frankfurt (Hahn), Gothenburg (City), Milan (Bergamo), Oslo (Sandefjord) Paris (Beauvais), Rome (Ciampino), Stockholm (Skavsta).
} 
Emirates, US Airways, Zoom). In contrast, British Airways struggled to maintain viable long-haul services from Glasgow. One of the few direct service initiatives undertaken by the airline was the link to New York JFK, which was launched in 1992. The carrier eventually withdrew services in 1998 after failing to attract sufficient volumes of business traffic. The viability of the route was further compromised by the absence of connecting flights offered to US destinations beyond New York, which would have been possible had its proposed alliance with American Airlines been approved (Kemp 1998). Lack of business traffic likewise contributed to the demise of direct services to Boston (Northwest Airlines) and Washington (United Airlines). Continental Airlines, in contrast, has managed to sustain a very successful year-round New York Newark service since 1998. The US-based carrier offers the advantage of connections through its Newark hub to a wide range of destinations in North and Central America (Stokes, 1998). While Edinburgh managed to secure a daily Continental flight to Newark in June 2004, Glasgow continues to be the preferred gateway for long-haul services attracting direct services to Dubai (Emirates) Philadelphia (US Airways) and Toronto (Air Canada).

In contrast to Glasgow, the number of international direct flights from Aberdeen remained generally stable during the 1990s. During this period, the airport sustained links to Amsterdam, Bergen, Esbjerg and Stavanger. Since 2002, Dublin (Ryanair), Groningen (bmi regional) and Paris CDG (Air France) have been added to its network of international destinations.

Although the number of direct connections from Glasgow appears to have improved after 2002, a high proportion of these new services were mainly to destinations in the long-haul (e.g. Dubai) and Southern European holiday markets (e.g. 
Alicante, Palma). Furthermore, in both markets, a high proportion of services were scheduled for the summer season and offered at low levels of service frequency (e.g. twice-weekly). Seasonal low frequency flights offered to mainly holidaying passengers resident in Scotland will be of marginal benefit to the Scottish economy whereas high frequency services to the global network hubs of major international airlines will help sustain economic development and attract additional inward investment though facilitating accessibility to markets and suppliers.

Figure 3 shows the number of gateway destinations served with a year round nonstop service operating at a frequency of greater than four flights per week from each Scottish airport during the period 1988 to $2004{ }^{6}$. During this period, Glasgow was replaced by Edinburgh as the preferred Scottish gateway for full service airlines offering direct services to hub airports in Europe. To a significant extent, regional subsidiary carriers operating services on behalf of major network airlines such as Air France have facilitated the growth of direct air services offered at Edinburgh. According to Denton and Dennis (2000), for network carriers it has become more commercially expedient to serve regional markets through sub-contracting routes to regional carriers who, with lower costs and more appropriate aircraft types, are better able to operate these services commercially. Network carriers are therefore able to use regional airlines to maintain their brand in low volume markets and to feed passengers onto their more profitable long-haul services. Passengers also, in theory should be able to receive the same service standards and benefits that would have been enjoyed had the service been operated directly by the network carrier. As shown in Table 2, of

\footnotetext{
${ }^{6}$ Gateways are defined as being those airports that process greater than five million passengers per year. This is consistent with the European Commission's definition of an international connection point. (European Union, 1996).
} 
the eighteen direct high frequency routes scheduled to European gateway airports from Scotland in June 2004, seven were operated exclusively by regional subsidiary carriers and two routes were operated by regional subsidiary carriers in competition with low cost airlines. Network carriers (CSA Czech Airlines, Aer Lingus, Icelandair, SAS) only offered services on four routes. This is in contrast to June 1992, where out of the eleven direct routes to European gateways, eight were operated by network carriers and the remaining three by an independent regional airline (Air UK).

The advantages to be gained by the regional airline in operating air services on behalf of a major network carrier could be applied to the circumstances surrounding the collapse of Duo and its Edinburgh services in May 2004. The airline under its previous name (Maersk Air UK) functioned as a British Airways regional franchise carrier based at Birmingham. The benefits of this arrangement included the considerable marketing advantages and cost savings involved in securing access to the frequent flyer programme and sales distribution networks of British Airways. Remodelling itself as an independent airline, Duo sought to position itself as a "lower cost airline" offering a level of service in addition to that generally provided by traditional "no-frills" carriers. According to a former senior manager, the airline's business plan was flawed because it adopted a direct sales strategy rather than using a global distribution system and insufficient funds were budgeted for advertising, especially in non-UK markets where brand awareness was poor (Clarke, 2004).

Ryanair remains the dominant UK-based low cost airline offering direct international services in the Scottish market. In addition to securing first-mover advantage in the market, the carrier was also able to develop more successfully using the lower cost platform available at Prestwick where charges were substantially less 
than at BAA Scotland-owned Glasgow and management appearing to be much more amenable to the Ryanair business proposition. In contrast, Easyjet turned-down the opportunity to establish a Scottish base because it was unable to reach agreement with BAA Scotland on airport charges.

\section{$4 \quad$ Key factors}

\subsection{Social and economic factors}

One of the underlying drivers of direct international air services provision is the scale and spatial distribution of business and leisure travel demand.

Business passengers are particularly attractive to scheduled airlines as they tend to travel more frequently and are also generally prepared to pay higher prices than leisure travellers (Shaw, 1985). A region's demand for business air travel is determined by the presence of sectors of the economy that are frequent users of air services. According to Mason (2004), banking and finance followed by insurance and pension funds are the most 'air intensive' sectors. Analysis of Scottish air traffic demand showed that employment in 'air intensive sectors' was greater within Edinburgh airport's catchment area compared to Glasgow's (Department for Transport, 2003a). Table 3 shows the higher proportion of economic activity accounted for by banking and finance in Edinburgh, in particular the role of foreign-based institutions. Edinburgh's dual role as a major financial centre (sixth largest in Europe) and centre of public administration in Scotland helps explain why some full service carriers, such as Air France and Lufthansa prefer to operate from Edinburgh rather than Glasgow. The advantage enjoyed by Edinburgh is also reflected in an analysis of the location and ownership of foreign companies that have invested in Scotland. For example, there are 268 foreign companies located within Edinburgh airport's catchment area 
compared to 91 in Glasgow's. There are a further 150 companies located in Lanarkshire where both airport catchment areas overlap. Export trends will also affect patterns of business travel between regions. While the value of manufactured exports produced by companies located in both catchment areas is similar, service sector exports (e.g. financial services) are much more significant from companies located within Edinburgh's catchment area (Department for Transport, 2003b).

Tourism, both outbound and inbound, is also a significant driver in both the scale and geographic location of direct international services. In the short-haul market, a significant proportion of outbound tourism to international destinations has historically been in the form of package holidays with flights operated by charter rather than scheduled carriers. Increased demand for seat-only travel in recent years has prompted low cost carriers to offer services to several major European cities and holiday resorts. Rather than operate from Edinburgh, with its larger catchment area, Ryanair opted for Prestwick where the emphasis appears to have been on securing favourable terms and conditions from the airport operator. Seat-only services are also offered by Air Scotland and Flyglobespan to both Mediterranean resorts (Alicante, Malaga, Palma) and some major European cities (Athens, Barcelona, Rome). Both carriers have avoided head-to-head competition with Ryanair at Prestwick and instead are offering services from Edinburgh and Glasgow. However, on most of these routes frequency is limited to weekly or twice weekly services.

Scotland is an important tourist destination, attracting 1.6 million overseas visitors in 2003 with $82 \%$ travelling by air. Of those visitors that arrive by air, 55\% used direct scheduled services to Scottish airports, with the remaining $45 \%$ having arrived and departed on connecting flights. The most visited city is Edinburgh, where four 
out of the top five tourist attractions are located. The most important overseas market is the US, which accounts for $26 \%$ of visitors. Although Edinburgh appears to host most of the tourist attractions, the majority of direct services from the US are scheduled from Glasgow. This is because; firstly, being the busiest airport, Glasgow has historically tended to be perceived by the airline industry as Scotland's principal international gateway, and secondly, facilities for handling large narrow body aircraft (Boeing 767) on long-haul services are more extensive in Glasgow compared to Edinburgh.

In the short-haul market, which is dominated by visitors from Germany, France and Italy, Edinburgh appears to be the more preferred gateway for several carriers primarily catering for the tourist market such as Germanwings, Hapag-Lloyd Express and SAS (seasonal service). With user charges very similar at Edinburgh and Glasgow the only added value offered by the former is its proximity to key tourist attractions, and from the perspective of developing the outbound leisure market, a greater population catchment area compared to both Glasgow and Prestwick airports.

\subsection{Use of regional jets}

Air service networks are shaped to a significant extent by the operating capabilities and economics of aircraft technology. The introduction of regional jets in the thirty to fifty-seat category has enabled airlines to operate routes that were previously too long in terms of sector distance for conventional turboprops and too thinly trafficked to support a Boeing 737-series aircraft. Fifty-seat regional jets such as the Bombardier CRJ-200 and Embraer ERJ-145 have sufficient range to operate routes which by-pass hub airports. The Embraer ERJ series, which includes the smaller ERJ-135, are to be found in the fleets of increasing number of European regional airlines (e.g. bmi 
regional,). Aberdeen - Paris CDG and Edinburgh - Paris CDG are examples of markets where regional jets replaced larger-sized aircraft, substituting single daily frequencies with schedules offering three daily return trips. For example, in the early 1990s Air France operated a daily Aberdeen-Paris CDG direct service using a Boeing 737-200, which involved an intermediate stop at Glasgow. This service was eventually withdrawn in 1992. Ten years later, Air France resumed direct services, offering a three-times daily service using an Embraer-135 operated by Régional Airlines under a franchise agreement. On busier markets, however, such as Dublin and Amsterdam, it is common to find Boeing 737-series jets, which are generally associated with lower unit costs and also often used by low cost airlines (Easyjet and Ryanair).

\subsection{Absence of base carrier and availability of connecting services}

The presence of a base carrier or national airline will have an impact on the range and volume of international connections that are offered. When air transport was heavily regulated and subsidised, governments ensured that their country had access to international destinations through establishing a national air carrier. The national carrier would often have been granted exclusive rights as the designated flag airline to serve international destinations under bilateral air service agreements. Therefore, countries with relatively small population sizes such as Iceland, Malta and the Republic of Ireland ensured access to other countries through services provided by the national airline, which was often state-owned and subsidised. However, deregulation in the 1990s and the gradual withdrawal of state aid has to a large extent called into question the commercial sense in the flag carriers of smaller states (Olympic Airways, Sabena, Swiss) maintaining over-extended route networks inherited from a period of 
characterised by limited competition and regular subsidy.

Prior to deregulation, UK bilateral international air service agreements usually designated British Airways as the UK carrier. Furthermore, the same agreements would sometimes limit international services to operating from London Heathrow. This restricted the ability of airlines to develop networks of international air services at UK regional airports, at least up until the late 1980s.

While deregulation has enabled direct services to flourish at many UK regional airports, Scottish airports have to some extent been disadvantaged because of their geographic location. Situated on Europe's Northwestern periphery, carriers such as British Airways, bmi and Flybe have found it more commercially expedient to serve the Scottish international market through offering connecting flights between Scotland and Continental Europe via Birmingham, Manchester or London Heathrow. The development of the 'Eurohub' at Birmingham in the early 1990s by British Airways was an attempt to develop a 'hub and spoke' network where services to various European airports from Birmingham would be closely coordinated with feeder flights from Scotland and Northern Ireland with short connection times between services. During this period some direct flights from Scotland were withdrawn and replaced by connecting services, some of them marketed as direct flights. For example, British Airways withdrew its daily non-stop Glasgow-Paris CDG service in 1995 replacing it with several direct flights all involving an intermediate stop en route at Birmingham, leading to a significant increase in overall travel time between both cities.

Consolidating traffic through a hub airport allows for a higher frequency service to be offered which is of particular appeal to business passengers. Leisure passengers will also benefit in some instances from lower fares offered by connecting carriers. 
Firstly, economies of density and the use of larger aircraft on hub and spoke networks mean lower unit costs (Lijesen et al, 2002). Secondly, connecting carriers, in seeking to improve load factors on specific flight segments, may offer substantially discounted fares on a limited range of seats to passengers connecting from other airports in the network.

The absence of base carriers of significant size has meant that Scottish airports have tended to function as spokes rather than hubs within airline networks. Under these circumstances services are much more susceptible to withdrawal in contrast to the stability and expansion of services that is often a feature of base carriers that have substantial sunk investments and established operations at an airport.

\subsection{Airport Competition}

BAA Scotland's control of Aberdeen, Edinburgh and Glasgow has been cited as one of the main contributory factors behind the decline and stagnation of international air service provision at Glasgow (Currie, 2002). Market dominance in the airport sector can be manifested in operator inflexibility in setting levels of airport aeronautical charges. Go, prior to its takeover by Easyjet, and Easyjet itself have made frequent reference to the high level of aeronautical charges levied at Edinburgh and Glasgow, citing this as the main barrier to establishing networks of services at these airports (Nichols, 2001). It has often been recommended that in order to facilitate a competitive environment, BAA Scotland's airports should be owned and operated independently (Leask, 2002). Indeed, the sale of Prestwick airport by BAA in 1992 and its subsequent growth and development perhaps serves as an example of the positive effects of greater airport competition.

In seeking to attract airlines, many airports offer incentives such as discounts on the 
level of published aeronautical charges. Low cost airlines, given the nature of their operations and business model are likely to be the first carriers to react to pricing initiatives given that airport user charges account for a fairly significant proportion of their total operating costs. Ryanair, for example in March 2004, transferred a proportion of capacity on their Dublin-Birmingham route to Nottingham in response to an increase in charges levied by Birmingham Airport. (Moores, 2004). The ease with which some carriers are able to transfer operations, perhaps suggests that the market for airport access is highly elastic. However, elasticity depends on the type of airline. Long-haul and full service carriers may not react in the same way as low cost airline to price changes as their choice of airport is also influenced by quality of airport facilities and surface accessibility. Actually, one low cost carrier Flyglobespan, decided to relocate from Prestwick to Glasgow because the latter airport was perceived as offering better value than the former in terms of US market recognition (Moores, 2003).

The initiative undertaken by BAA Scotland in 2002 to establish its own route development fund with an investment of $€ 85$ million perhaps suggests that the company is sufficiently incentivised to promote its airports without the need for competition. Indeed, in separating ownership and management, the three airports may lose the benefits of economies of scale where funds needed to finance capital expenditure and marketing initiatives can be more readily facilitated through drawing on the considerable financial resources of the BAA group.

\subsection{Government support for air services}

The Scottish Executive has very few direct responsibilities for civil aviation in Scotland. However, one significant initiative undertaken was the setting-up of a route development fund to help support new direct air services. 
The Interim Route Development Fund (IRDF) was established, with a budget of around $€ 8.5$ million in 2002. It is managed by Scottish Enterprise, which is a development agency sponsored by the Scottish Executive. Provided air service initiatives are able to demonstrate that business links will be improved and additional inbound tourist traffic will be generated, the fund finances discounts on aeronautical charges up to a maximum of $75 \%$ of passengers on each flight over a three-year period. The fund also requires a matching commitment from the airport operators.

Table 4 shows that by June 2004 seven route initiatives were supported at Edinburgh, six at Prestwick and one each at Aberdeen, Glasgow, Inverness and Kirkwall. Low cost carriers were involved in eight direct route initiatives, with the remaining nine operated by full service airlines. Ryanair has been the largest recipient of support securing assistance for six of its new routes from Prestwick. However, of those routes supported by IRDF assistance, only nine have survived. Duo's five routes were withdrawn following the collapse of the airline, while new services offered by Germania, Loganair and Snowflake were also discontinued.

The fact that a sizeable proportion of the initiatives supported by the fund have failed perhaps serves to illustrate the limits of government start-up support where there are either flaws in the airline business proposition or there are risks to cash-flow and liquidity due to lower than expected traffic volumes. The precise levels of support awarded to each initiative are confidential, so it is difficult to ascertain whether levels of assistance were adequate. Analysis of the discontinued air services does show that the majority were initiatives launched by new start-up carriers with limited experience of serving the Scottish market (Duo, Germania, Snowflake). Furthermore, it is interesting to note that several of the new direct service initiatives undertaken since 
2002 by major network carriers and their regional affiliates (Air France, CSA Czech Airlines, Lufthansa, SAS) have been sustained without IRDF support. Indeed, there may even be an issue of whether it is more desirable to support start-up initiatives through subsidising marketing and promotional activities rather than on discounting aeronautical charges. Experience of travel banks in the United States in supporting new air service initiatives from regional airports perhaps suggests that market-based, demand-led solutions are more effective ${ }^{7}$. However, this supposition is based on how highly airlines value lower aeronautical charges relative to additional marketing and promotional activity. The fact that recurrent criticism of the level of aeronautical charges set by BAA Scotland have been levelled by several air carriers perhaps suggests that this is a primary hurdle to developing new air services in Scotland.

\section{Conclusions}

The development of direct air services has historically been constrained by Scotland's relatively low population size and remote location relative to Mainland Europe. The absence of established and significantly-sized base carriers has meant that Scottish airports typically function as "spokes" within airline networks and are thus more susceptible to changes in levels of service. The geographic distribution and level of direct services has been shaped to a significant extent by the effects of air service deregulation. The loss of Prestwick's exclusive transatlantic gateway status precipitated the transfer of all long-haul services to Glasgow. Although some of these were subsequently withdrawn, the airport has retained its status as Scotland's principal gateway for long-haul services. In the same period, Glasgow has not managed to retain its short-haul international connections.

\footnotetext{
${ }^{7}$ For a discussion of travel banks please refer to (General Accounting Office, 2003)
} 
One significant effect of deregulation has been the emergence of low cost carriers. Ryanair, lured by generous terms and conditions, preferred to establish its network of short-haul services at Prestwick where it now offers services to more European destinations that Glasgow. While network carriers have struggled in sustaining services from Glasgow, Edinburgh offers a more appealing business proposition where the presence of the Scottish Parliament, a significant business and financial community and the city's tourist attractions offers greater scope to schedule commercially viable air services. However, as major network carriers have become progressively more disengaged from operating in regional markets, the potential loss of air service connections has been averted by the franchising of services to regional airlines. Lower costs and the use of regional jets means that major hubs can be served with high levels of service frequency and flights can be scheduled to new destinations that could not be served profitably using conventional jet and turboprop aircraft. Several major network carriers have made use of regional franchise airlines and subsidiaries to operate high frequency regional jet services from Edinburgh and to a lesser extent Aberdeen.

The improvement in the level and range of direct services scheduled after 2002 to a large extent has been due to the efforts of Prestwick Airport Ltd and BAA Scotland in marketing and promoting their airports to potential airlines. It is unlikely that breaking-up BAA Scotland into three separately owned and managed airports would create substantial benefits in terms of additional marketing and promotion. Indeed, the advantages of drawing on the significant resources of the BAA group both for capital expenditure and marketing support would in fact be lost. Less effective has been the much-vaunted Scottish Executive Route Development Fund where since its inception, a significant number of supported initiatives have been withdrawn. 


\section{Acknowledgments}

The author would like to express his gratitude to Dr George Williams for his advice and support and to Mr Kenny MacAskill MSP for his insightful and valuable comments on initial drafts of this paper. 


\section{References}

Calder, C,. 1994. Air deal branded suicide, The Times, 14 April 1994, London.

Clark, M,. 2004. Business plan flawed. Article in Travel Weekly, 10 May 2004, Sutton (UK).

Currie, B., 2002. Glasgow 'treated like a backwater airport'; SNP attacks BAA and says Holyrood must 'direct the flight path'. Evening Times, 6 June 2002, Glasgow.

Denton, N., Dennis, N., 2000 Airline franchising in Europe: benefits and disbenefits to airlines and consumers. Journal of Air Transport Management. 6, 179-190.

Department for Transport, 2003a. The future development of air transport in the United Kingdom: Scotland, Department for Transport, London.

Department for Transport, 2003b. The future development of air transport in the United Kingdom: Scotland, Review of air traffic forecasts for airports serving the Central Belt of Scotland prepared by Arup Consulting with Transport Research Institute and Scott Wilson, Department for Transport, London.

European Union, 1996. Official Journal of the European Communities, L228, 23 July, European Union, Brussels.

General Accounting Office. 2003. Factors affecting efforts to improve air service at small community airports. GAO-03-330, US General Accounting Office, Washington, DC.

Hughes, P,. 2004 The Air Route Development Fund: a progress report. Scottish Transport Review, 24, 11.

Kemp, K., 1998. BA grounds its Glasgow transatlantic service, The Scotsman, 19 
November, Edinburgh.

Leask, D., 2002. MPs call for end of airport monopoly. Evening Times, 2 December, Glasgow.

Lijesen, M,. Rietveld, P,. Nijkamp, P,. 2002. How do carriers price connecting flights? Evidence from intercontinental flights from Europe. Transportation Research Part E. 38 (3-4), 239-252.

Mackinlay, J,. 1999. Benefits of the direct approach. The Herald, 30 March 1999, Glasgow.

Mason, N., 2004. The economic impact of airports. Paper presented at the 2004 Airport Economics and Finance Symposium, London.

Moores, V., 2003. Flyglobespan stops Prestwick ops, mulls long-haul. Air Transport Intelligence, 25 September 2003, www.rati.com.

Moores, V., 2004. Ryanair switches some Birmingham flights to Nottingham. Air Transport Intelligence, 17 March 2004, www.rati.com.

Nichols, M,. 2001. High costs deter cheap flights. The Scotsman, 28 November 2001, Edinburgh.

Shaw, S,. 1985. Airline marketing and management ( $2^{\text {nd }}$ edn ed), Pittman, London.

Stokes, B,. 1998. BA leaves skies clear for new transatlantic era. Scotland on Sunday 22 November, Edinburgh. 
Figure 1: Map of Scotland

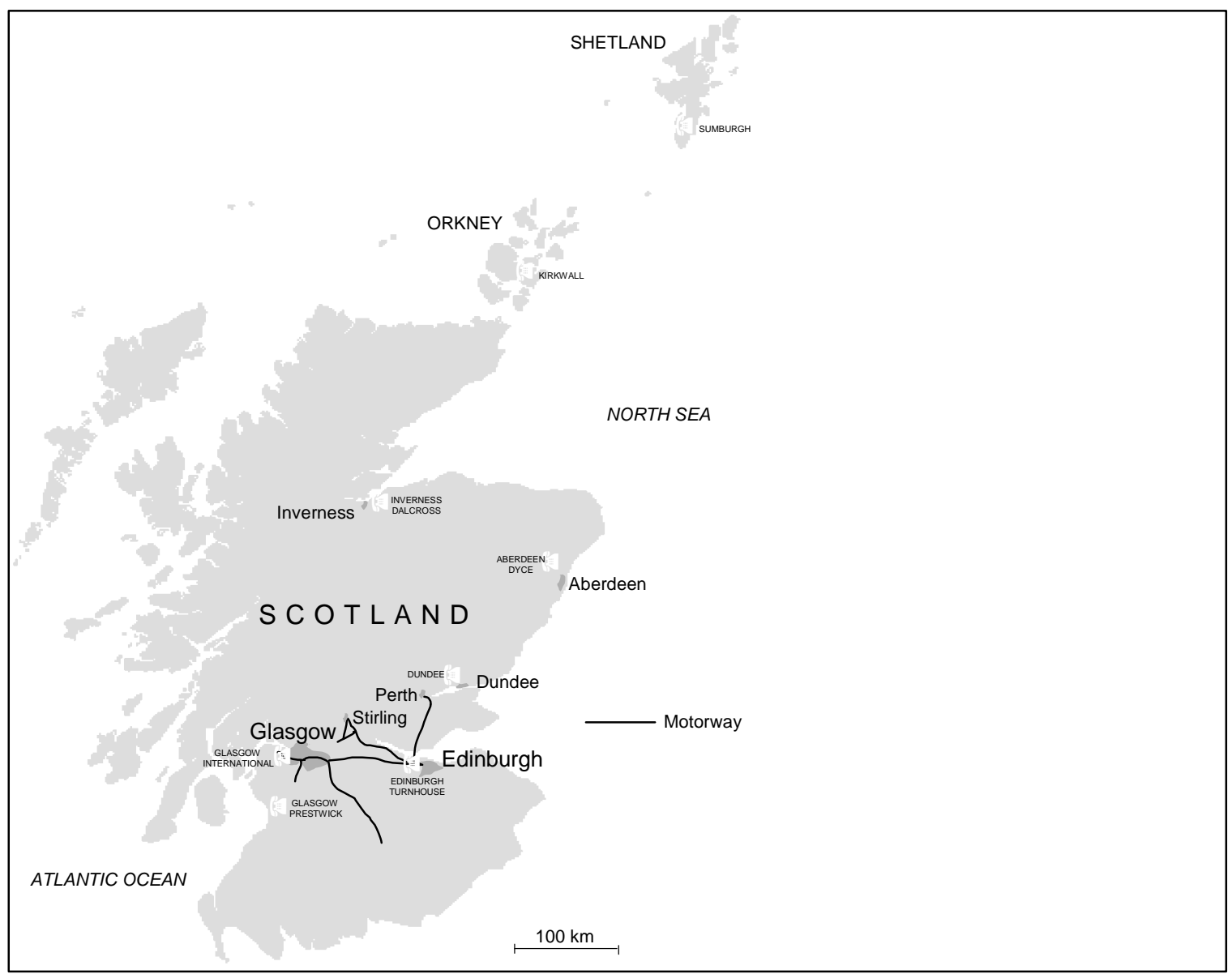


Figure 2: Total number of direct non-stop international routes scheduled at Aberdeen, Edinburgh, Glasgow and Prestwick (June 1988 to June 2004)

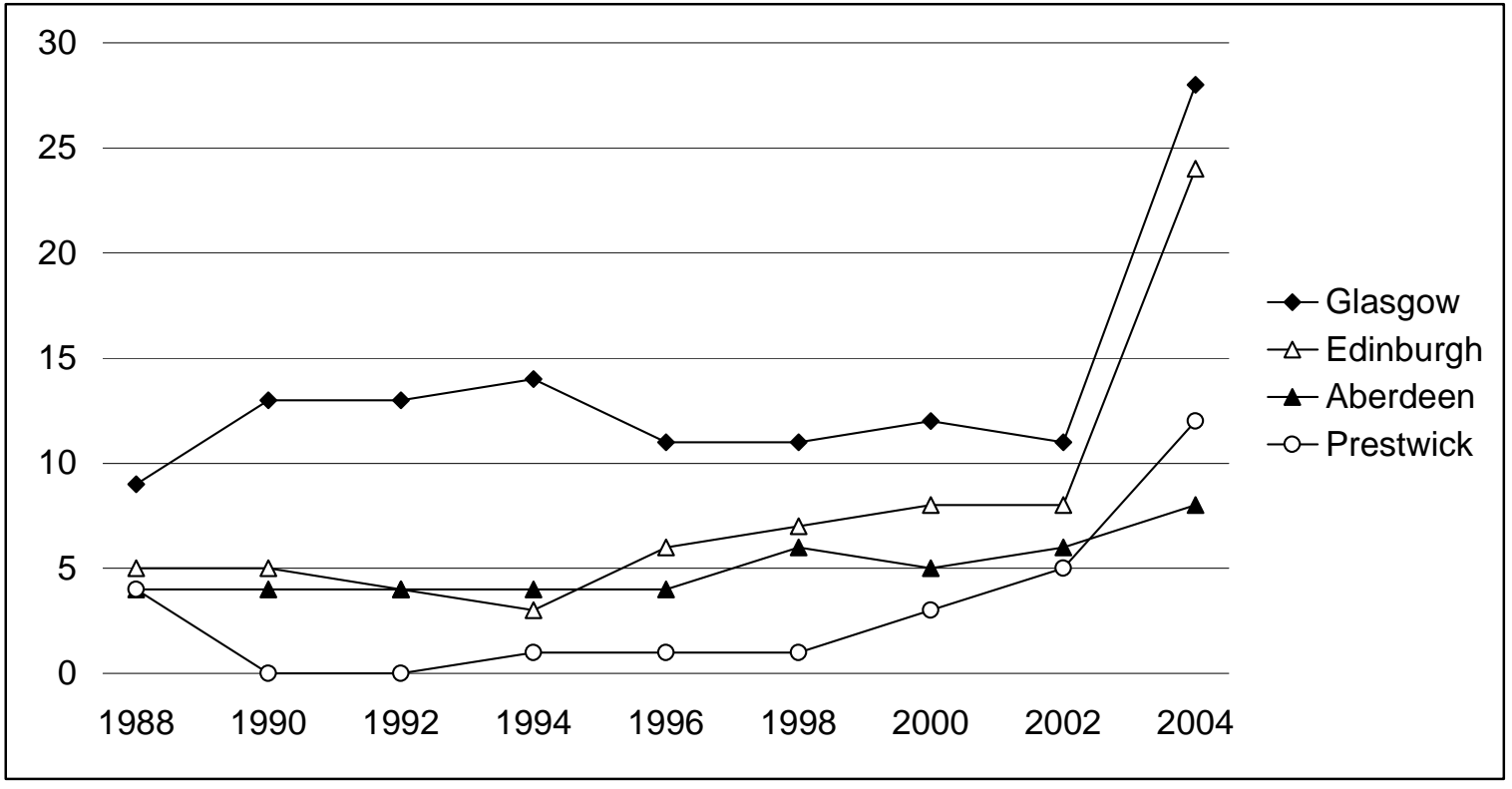

Source: Official Airlines Guide 
Figure 3: Total number of non-stop high frequency ${ }^{1}$ direct routes to gateway airports from Aberdeen, Edinburgh, Glasgow \& Prestwick (June 1988 to June 2004)

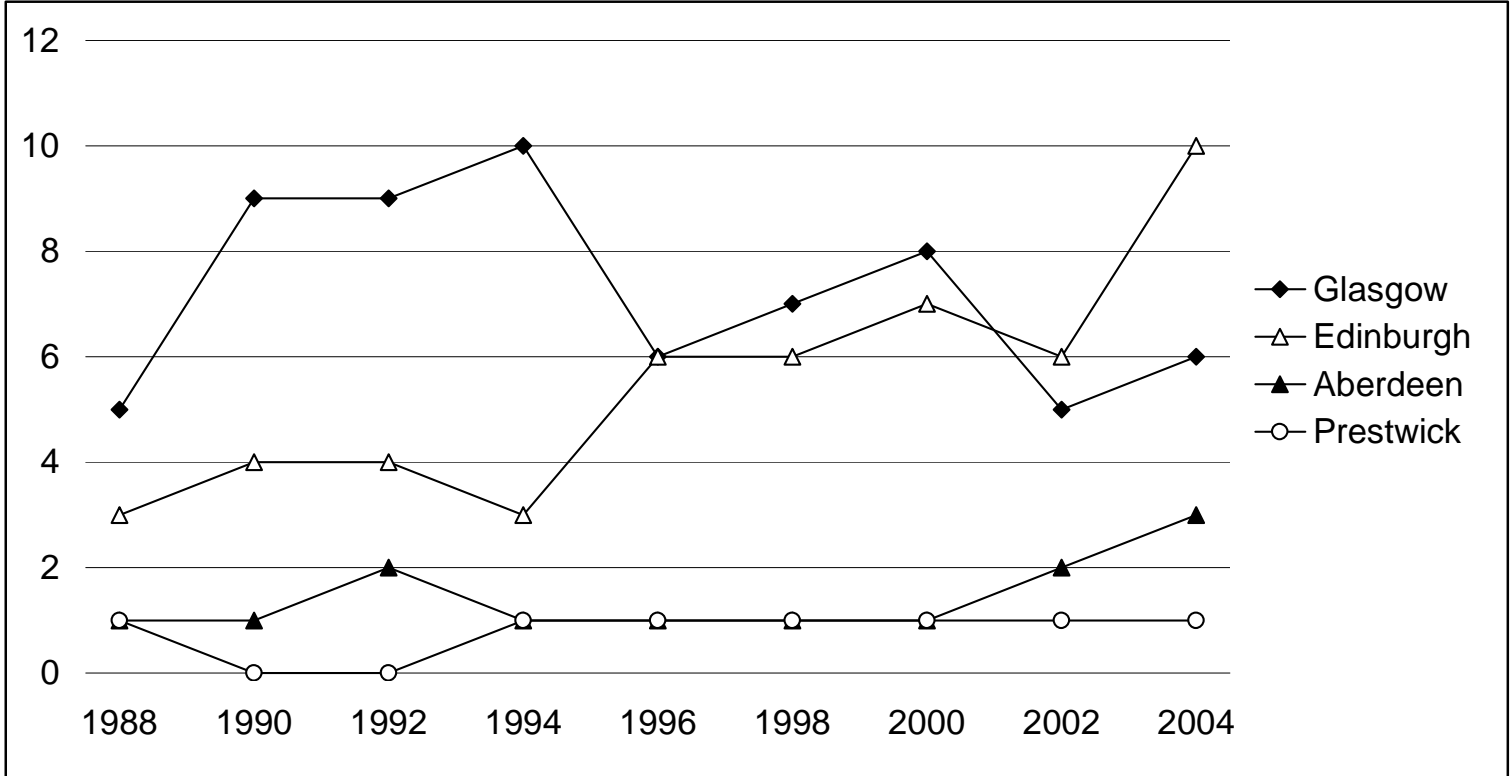

Source: Official Airlines Guide

${ }^{1}$ Greater than four flights per week 
Table 1: Top 15 busiest international routes from Scotland in 2003

Route

Passenger traffic in 2003

Edinburgh-Amsterdam

Edinburgh-Dublin

Glasgow-Amsterdam

Prestwick-Dublin

Aberdeen-Amsterdam

Glasgow-Dublin

Edinburgh-Paris CDG

Edinburgh-Frankfurt

Prestwick-Paris Beauvais

Glasgow-Newark

Aberdeen-Stavanger

473,929

413,053

347,123

231,365

210,025

181,415

166,782

164,690

141,707

128,366

114,350

100,236

Prestwick-Frankfurt Hahn

85,337

75,498

Glasgow-Toronto

70,614

Source, UK Civil Aviation Authority 
Table 2: Number of high frequency short-haul routes to European gateway airports by type of carrier June 2004

\begin{tabular}{lccccc}
\hline Airport & $\begin{array}{c}\text { Regional } \\
\text { Subsidiary } \\
\text { or Franchise } \\
\text { monopoly }\end{array}$ & $\begin{array}{c}\text { Low cost } \\
\text { monopoly }\end{array}$ & $\begin{array}{c}\text { Regional } \\
\text { Subsidiary or } \\
\text { Franchise \& Low } \\
\text { cost duopoly }\end{array}$ & $\begin{array}{c}\text { Network carrier } \\
\text { monopoly }\end{array}$ & $\begin{array}{c}\text { Network \& Low } \\
\text { cost duopoly }\end{array}$ \\
\hline Aberdeen & 1 & 1 & 0 & 0 & 0 \\
Edinburgh & 4 & 1 & 1 & 2 & 1 \\
Glasgow & 2 & 1 & 1 & 0 & 0 \\
Prestwick & 0 & 1 & 0 & 4 & 0 \\
Total & 7 & 4 & 2 & & 1 \\
\hline
\end{tabular}


Table 3: \% breakdown of organisations by sector (Edinburgh and Glasgow) in 2000

\begin{tabular}{lcccc}
\hline Sector & \multicolumn{2}{c}{ Edinburgh } & \multicolumn{2}{c}{ Glasgow } \\
& UK business & $\begin{array}{c}\text { Foreign } \\
\text { Business }\end{array}$ & UK business & $\begin{array}{c}\text { Foreign } \\
\text { Business }\end{array}$ \\
\hline Agriculture & 1.3 & 1.3 & 0.5 & 0.2 \\
Energy \& water supply & 3.5 & 3.6 & 2.9 & 2.6 \\
Extraction processes & 2.4 & 3.5 & 3.8 & 5.9 \\
Engineering & 12.8 & 13.7 & 15.7 & 30.0 \\
Other manufacturing & 7.7 & 4.5 & 7.4 & 6.0 \\
Construction & 2.9 & 2.4 & 4.0 & 1.1 \\
Distribution \& catering & 14.5 & 11.3 & 11.9 & 11.2 \\
Transport \& communications & 5.0 & 3.3 & 9.2 & 9.3 \\
Banking \& finance & 25.0 & 24.6 & 19.9 & 12.4 \\
Public administration & 24.9 & 31.9 & 24.8 & 21.3 \\
\hline
\end{tabular}

Source, Scottish Executive 
Table 4: Interim Route Development Fund statistics

\begin{tabular}{lll}
\hline Route & \multicolumn{1}{c}{ Airline } & \multicolumn{1}{c}{ Launch date } \\
\hline Edinburgh - Cologne/Bonn & Germanwings & March 2003 \\
Prestwick - Stockholm Skavsta & Ryanair & April 2003 \\
Prestwick - Gerona & Ryanair & April 2003 \\
Kikrwall - Bergen & Loganair & June 2003 ${ }^{21}$ \\
Prestwick - Berlin Tegel & Germania & August 2003 \\
Edinburgh - Milan Malpensa & Duo & October 2003 \\
Edinburgh - Zurich & Duo & October 2003 \\
Edinburgh - Oslo & Duo & October 2003 \\
Edinburgh - Geneva & Duo & October 2003 \\
Prestwick - Gothenburg & Ryanair & October 2003 \\
Prestwick - Milan Orio al Serio & Ryanair & January 2004 \\
Edinburgh - Newark & Continental & March 2004 \\
Inverness - Stockholm Arlanda & Snowflake & March 2004 ${ }^{1}$ \\
Glasgow - Dubai & Emirates & March 2004 \\
Edinburgh - Munich & Duo & March 2004 \\
Prestwick - Rome Ciampino & Ryanair & March 2004 \\
Aberdeen - Groningen & Bmi regional & May 2004 \\
\hline
\end{tabular}

${ }^{1}$ Discontinued

${ }^{2}$ Summer Only 